\title{
Tolerance of benthic macrofauna to hypoxia and anoxia in shallow coastal seas: a realistic scenario
}

\author{
${\text { Bettina Riedel }{ }^{1, *}, \text { Martin Zuschin }^{2} \text {, Michael Stachowitsch }}^{1}$ \\ ${ }^{1}$ Department of Marine Biology and ${ }^{2}$ Department of Paleontology, University of Vienna, Althanstrasse 14, Vienna 1090, Austria
}

\begin{abstract}
Oxygen depletion can lead to the collapse of benthic ecosystems, i.e. to dead zones, and large-scale biodiversity loss. Based on mortality and survival, we evaluated ranges of sensitivity and tolerance to hypoxia levels, duration of anoxia and $\mathrm{H}_{2} \mathrm{~S}$ exposure across taxa and key life habits. Experiments were conducted on a sublittoral soft-bottom under realistic in situ conditions in a community setting featuring both a well-developed epi- and infauna. Overall, 495 individuals representing 40 species were examined over almost $1000 \mathrm{~h}$ (using time-lapse camera and sensor arrays). Mortality started at dissolved oxygen (DO) concentrations $<0.5 \mathrm{ml} \mathrm{l}^{-1}$ and centred at the transition from severe hypoxia to early anoxia. A total of $58 \%$ of the individuals belonging to 27 species died. Thirteen species (39 individuals) died exclusively during anoxia. All of the individuals that died during hypoxia, and most of those that died during anoxia, did so before the onset of hydrogen sulphide $\left(\mathrm{H}_{2} \mathrm{~S}\right)$. In 11 species, all individuals survived: survival rates were highest among molluscs, anthozoans and ascidians. In contrast, most polychaetes, decapods and echinoderms died. Epifauna was more vulnerable than infauna, mobile forms were more vulnerable than sessile forms, and predators more vulnerable than deposit-feeders and suspension-feeders. While hypoxia primarily affected total abundance, anoxia significantly reduced the number of species. The former represents a quantitative, the latter a qualitative decline in ecosystem function. Most of the macrofauna may initially survive shorter-term (day-long) or intermittent hypoxia, but the onset of anoxia marks community collapse and biodiversity loss.
\end{abstract}

KEY WORDS: Benthic community - Oxygen - Dead zone Survival $\cdot$ Mortality $\cdot$ Life habit · Mediterranean

Resale or republication not permitted without written consent of the publisher

\section{INTRODUCTION}

Many marine ecosystems have deteriorated to a point that scientific publications increasingly focus on ecosystem dysfunction (Jackson et al. 2001, Worm et al. 2006, Jackson 2008) by documenting deterioration, identifying indicators and indices of habitat quality and suggesting management strategies (Link 2005, Salas et al. 2006, Butchart et al. 2010). This is most evident in shallow coastal seas, which bear the brunt of virtually all anthropogenic disturbances (Lotze et al. 2006, Halpern et al. 2008).

Among such threats, in particular eutrophicationpromoted hypoxia (dissolved oxygen $[\mathrm{DO}]<2.0 \mathrm{ml} \mathrm{l}^{-1}$;
Diaz \& Rosenberg 1995) and anoxia can depauperate and 'homogenise' benthic communities or even eliminate the macrofauna entirely (Sala \& Knowlton 2006). This changes ecosystem structure and function (Gray et al. 2002, Solan et al. 2004, Levin et al. 2009, Middelburg \& Levin 2009) and leads to destabilisation (Conley et al. 2009, Rabalais et al. 2010, Zhang et al. 2010). One endpoint is widespread ecosystem collapse. Accordingly, ecosystems suffering from intermittent or recurring hypoxia or anoxia are among the most extreme marine environments based on both the severity of conditions and the instability or unpredictability of disturbance. Global warming is expected to increase the vulnerability of benthic macrofauna 
to reduced oxygen levels (Vaquer-Sunyer \& Duarte 2010) and thus accelerate biodiversity loss (Keeling et al. 2010, Gruber 2011).

Much of the available information about the impact on benthic systems comes from laboratory experiments on individual species (e.g. Shimps et al. 2005, Long et al. 2008, Wang et al. 2010), from a piecemeal fabric of in situ documentations (e.g. Stachowitsch 1984) and, increasingly, from syntheses based on organisms from different communities, laboratory and field studies and different geographic regions (e.g. Vaquer-Sunyer \& Duarte 2008, Farrell \& Richards 2009). Our efforts are designed to fortify one cornerstone of these approaches, namely, to document the impact on the benthos within the same benthic community, in the field, over the entire course from the onset of hypoxia to mortality. The in situ experimental design (Stachowitsch et al. 2007) yields a more holistic picture by concurrently presenting individual- to community-level responses from different perspectives (i.e. behavioural reactions, intra- and interspecific interactions and mortality sequences).

Here, we build upon traditionally accepted oxygen thresholds and examine them in a community setting. We define sensitivity or tolerance based on the sequence of mortality and on survival at various taxonomic levels in relation to hypoxia and duration of anoxia. We also consider 'life habits', i.e. substrate relationship, mobility and feeding type. The results, combined with behavioural studies, will provide information on the sensitivity and function of the benthic compartment and will help to better interpret post-hypoxia or anoxia community composition and recovery potential.

\section{MATERIALS AND METHODS}

\section{Study site and experimental design}

The Northern Adriatic Sea (Mediterranean) is among the ca. 400 dead zones recognized by Diaz \& Rosenberg (2008) and combines most features that characterise coastal ecosystems sensitive to low oxygen events (e.g. semi-enclosed basin, shallow depth, soft bottom, high productivity and stratification; Stachowitsch \& Avcin 1988). This model system shows classical symptoms of long-term anthropogenic eutrophication (Justic 1987), including repeated mortalities (e.g. Fedra et al. 1976, Stachowitsch 1984, Hrs-Brenko et al. 1994), and is especially interesting in featuring both a well-developed infauna and macroepifauna (Zuschin \& Stachowitsch 2009). The investigated community was named the OphiothrixReniera-Microcosmus (ORM) community by Fedra et al. (1976) based on the 3 dominant genera (the brittle star Ophiothrix quinquemaculata, the sponge Reniera spp. and the ascidian Microcosmus sulcatus).

Eleven deployments of a specially designed camera- and sensor-equipped benthic chamber were made in September 2005 and August to October 2006 in a soft-bottom habitat (poorly sorted silty sand) in $24 \mathrm{~m}$ depth in the Gulf of Trieste, Northern Adriatic Sea $\left(45^{\circ} 32^{\prime} 55.68^{\prime \prime} N, 13^{\circ} 33^{\prime} 1.89^{\prime \prime} \mathrm{E}\right)$. This position is adjacent to the oceanographic buoy of the Marine Biology Station Piran and is one of the few sites in the Gulf unaffected by bottom fisheries, a key criterion for physically intact benthos and secure equipment deployment. Moreover, this site has not been affected by hypoxia for at least 5 yr before our experiments (V. Malacic pers. comm.), providing a biologically intact community including the larger epifaunal multi-species clumps that characterise the Gulf of Trieste (Fedra et al. 1976).

The underwater device was used to experimentally induce small-scale anoxia and quantify macrobenthic responses (for a detailed description of the method, see Stachowitsch et al. 2007). The design involves the successive use of 2 interchangeable bases of the same size $(50 \times 50 \times 50 \mathrm{~cm})$. Initially, the 'open' configuration (aluminium frame plus separate instrument lid) was positioned for ca. $1 \mathrm{~d}$ above a benthic assemblage to document macrofaunal behaviour during normoxia. Then, in a second step, the 'closed' configuration (plexiglass chamber plus lid) was positioned over the same assemblage to document reactions to hypoxia and anoxia (ca. 3 to $4 \mathrm{~d}$ ). The plexiglass chamber, pressed ca. $4 \mathrm{~cm}$ into the sediment, prevented water exchange with the surrounding environment. The lid housed a digital camera, 2 flashes, a datalogger and the microsensor array for $\mathrm{DO}, \mathrm{H}_{2} \mathrm{~S}$ and temperature recording (Unisense ${ }^{\circledR}$ ). To detect potential stratification, DO was measured at 2 different heights ( 2 and $20 \mathrm{~cm}$ above the sediment); the $\mathrm{H}_{2} \mathrm{~S}$ sensor was positioned $2 \mathrm{~cm}$ above the sediment. $\mathrm{pH}$ was measured at the beginning and end of almost all deployments with a WTW TA 197 $\mathrm{pH}$ sensor. Images were taken in 6 min intervals, with the sensor values logged every minute. The flashes never triggered any visible reaction in the benthic invertebrates, either in the open or closed configuration, and were thus not considered to have caused stress or altered the course of events. The courses of all deployments were very similar, but the starting times and durations varied due to weather 
conditions, diving schedules and different enclosed fauna. After each deployment, all enclosed organisms (living and dead) were collected and preserved in a $4 \%$ formalin-seawater solution. We attribute all mortalities to our experimental set-up: based on the short timeframe of our experiments (days), we consider the natural mortality of the long-lived macrobenthos to be negligible compared to that induced by the rapid oxygen declines. The deployments followed institutional guidelines (Univ. of Vienna, Austria; Marine Biology Station Piran, Slovenia).

\section{Macrofauna data analysis}

The 11 deployments covered a total surface area of $2.75 \mathrm{~m}^{2}$ and yielded data on a representative spectrum of taxa, life habits and behaviours (the latter will be summarised elsewhere). Overall, 9953 images were produced, encompassing a documentation time of $995 \mathrm{~h}$ (hypoxia: $331.9 \mathrm{~h}$, anoxia: $336.5 \mathrm{~h}$ ). A total of 495 individuals were evaluated, representing 39 species and 1 species group (i.e. polychaetes, containing those individuals that could not be identified more precisely based on the photographs) (Appendix 1). The species represented by only 1 or a few individuals were evaluated in full, those by many individuals selectively (e.g. based on individuals that were continuously visible - after emergence in the case of infauna - and recognisable). Time-lapse movies (Adobe Premiere Pro CS4) combined the images for quick viewing (sample $4 \mathrm{~d}$ film available at http:// phaidra.univie.ac.at/o:87923). Death was defined as having occurred directly after the final activity was observed; based on the authors' long-term experience, this time-point was typically unambiguous (e.g. collapse of soft-bodied forms and various combinations of overturning, clear-cut body postures, discoloration). Survivorship curves of individuals, species and higher taxa and species' life habits were depicted in relation to hypoxia concentration $\left(\mathrm{ml} \mathrm{l}^{-1}\right)$ and anoxia duration. Importantly, the separation into hypoxia (based on DO concentration) and anoxia (duration) yielded a more detailed and more interpretable sequence and range of tolerances, whereby mortality was additionally examined in terms of $\mathrm{H}_{2} \mathrm{~S}$ concentration $\left(\mu \mathrm{M}_{i}\right.$ at time of mortality during anoxia). Oxygen categories are defined as normoxia $\left(\geq 2.0 \mathrm{ml} \mathrm{DO} \mathrm{l}^{-1}\right)$, mild $(<2 \mathrm{ml}$ $\mathrm{DO} \mathrm{l}^{-1}$, equivalent to $2.8 \mathrm{mg} \mathrm{O}_{2} \mathrm{l}^{-1}$ or $91.4 \mathrm{mM}^{\text {; Diaz \& }}$ Rosenberg 1995), moderate $\left(<1.0 \mathrm{ml} \mathrm{DO} \mathrm{l}^{-1}\right)$, or severe hypoxia $\left(<0.5 \mathrm{ml} \mathrm{DO}^{-1}\right)$ and anoxia. Significant $\mathrm{H}_{2} \mathrm{~S}$ refers to concentrations $>14 \mu \mathrm{M}$, as defined by Vaquer-Sunyer \& Duarte (2010). Life habits include sub- strate relationship (cryptic and non-cryptic epifauna or infauna), mobility (mobile or sessile) and 3 major feeding types (predators, suspension feeders or deposit feeders) (Appendix 1).

One-way repeated measures ANOVA was used to test, across deployments, the equality of means of abundance (individual, species and higher taxa) and species' life habits among key oxygen categories. Within-subject comparisons that violated the assumption of sphericity were Greenhouse-Geisser corrected. Bonferroni-adjusted pairwise comparisons were then used to further explore significant differences $(p<0.05)$. Analyses were performed using the SPSS 19.0 software package.

\section{RESULTS}

\section{Deployments}

During the open configuration, the DO concentration remained relatively constant within a particular deployment, ranging from 2.6 to $5.6 \mathrm{ml} \mathrm{l}^{-1}$ on the bottom and from 2.8 to $8.9 \mathrm{ml} \mathrm{l}^{-1} 20 \mathrm{~cm}$ above the sediment. After closing the chamber, oxygen values immediately fell, with both curves continuously approximating each other. This drop in oxygen solely reflects natural respiration rates: the light conditions at this depth are low, our experiment never contained macroalgae, and any photosynthesis by the microflora is apparently negligible (based on the rapid decline of oxygen) compared to the respiration rates of the enclosed fauna. Hypoxia was reached within ca. $1.5 \mathrm{~d}$ and anoxia within $3 \mathrm{~d}$ (Table 1). The rapidity of the oxygen decline varied among deployments, with the duration of hypoxia ranging from 11.4 to $52.9 \mathrm{~h}$ and 5.2 to $81.8 \mathrm{~h}$ for anoxia. $\mathrm{H}_{2} \mathrm{~S}$ developed in 10 deployments and started to increase soon after the onset of anoxia, with final values reaching $\sim 163.6 \mu \mathrm{M}$ (except deployment 11, with an intermediate peak of $300 \mu \mathrm{M})$. The course of a representative deployment, based on average values from Table 1, is presented in Fig. 1. The temperature within a particular deployment remained constant $\left(17.6\right.$ to $21.4^{\circ} \mathrm{C}$; Table 1$)$; the bottom water salinity was $38 \%$. The bottom water $\mathrm{pH}$ dropped from initially 8.2 to a minimum of 7.5 .

\section{Mortality}

Overall, 299 of 495 individuals died (60\%). These included representatives of 27 of the 40 species evaluated. During hypoxia, 135 individuals (14 species) 
Table 1. Deployment overview. No.: number of deployment; OC: open configuration (frame); CC: closed configuration (chamber); WW: wet weight; -: no data

\begin{tabular}{|c|c|c|c|c|c|c|c|c|c|}
\hline \multirow[t]{2}{*}{ No. } & \multirow{2}{*}{$\begin{array}{l}\text { Date } \\
\text { (d.mo.yr) }\end{array}$} & \multicolumn{2}{|c|}{ Duration deployment } & \multicolumn{2}{|c|}{ Duration CC } & \multirow{2}{*}{$\begin{array}{c}\mathrm{H}_{2} \mathrm{~S}(\mu \mathrm{M}) \\
\text { (average over } \\
\text { last hour) }\end{array}$} & \multirow{2}{*}{$\begin{array}{c}\text { Final } \\
\mathrm{pH}\end{array}$} & \multirow{2}{*}{$\begin{array}{l}\text { Tempe- } \\
\text { rature } \\
\left({ }^{\circ} \mathrm{C}\right)\end{array}$} & \multirow{2}{*}{$\begin{array}{c}\text { Total } \\
\text { biomass } \\
\text { (g WW } 0.25 \mathrm{~m}^{-2}\end{array}$} \\
\hline & & $\begin{array}{c}\mathrm{OC} \\
(\mathrm{h})\end{array}$ & $\begin{array}{l}\text { CC } \\
\text { (h) }\end{array}$ & $\begin{array}{l}\text { Hypoxia } \\
\text { (h) }\end{array}$ & $\begin{array}{c}\text { Anoxia } \\
\text { (h) }\end{array}$ & & & & \\
\hline 1 & $17-22.09 .05$ & - & 132.8 & 20.1 & 81.8 & 167.6 & - & 18.5 & 436.7 \\
\hline 2 & $24-27.09 .05$ & - & 69.4 & 46.1 & 5.2 & 5.5 & - & 17.8 & 682.1 \\
\hline 3 & $27.09-01.10 .05$ & - & 101.6 & 41.6 & 28.8 & 36.8 & - & 17.6 & 604.7 \\
\hline 4 & 05-08.08.06 & 22.4 & 48.3 & 12.5 & 22.9 & 5.2 & 7.9 & 18.8 & - \\
\hline 5 & $17-21.09 .06$ & 20.9 & 72.1 & 33.8 & 28.7 & 124.2 & 7.7 & 19.7 & 839.8 \\
\hline 6 & $21-24.09 .06$ & 21.7 & 41.9 & 22.7 & 8.5 & 0.0 & - & 20.4 & 526.3 \\
\hline 7 & 25-29.09.06 & 21.9 & 73 & 40.5 & 19.1 & 19.3 & 7.8 & 20.6 & 648.9 \\
\hline 8 & $29.09-02.10 .06$ & 22.7 & 40.3 & 16.7 & 13.9 & 11.8 & 7.9 & 21.4 & 629.2 \\
\hline 9 & 05-10.10.06 & 23.6 & 95.4 & 11.4 & 78.3 & 106.7 & 7.5 & 21.3 & 724.0 \\
\hline 10 & $10-14.10 .06$ & 25.4 & 75.2 & 33.6 & 24.2 & 18.2 & 7.8 & 21.3 & 631.6 \\
\hline 11 & $17-21.10 .06$ & - & 94.6 & 52.9 & 25.1 & 124.5 & 7.8 & 20.4 & 1042.7 \\
\hline
\end{tabular}

died (Fig. 2A). The most sensitive species was the bivalve Chlamys varia, with 1 juvenile dying at moderate hypoxia $\left(0.8 \mathrm{ml} \mathrm{DO} \mathrm{l}^{-1}\right)$ and a second at severe hypoxia $\left(0.5 \mathrm{ml} \mathrm{DO}^{-1}\right)$. The second most sensitive species were a group of decapods which died at concentrations ranging from 0.4 to $0.03 \mathrm{ml} \mathrm{DO} \mathrm{l}^{-1}$ (for details on median and range values, see Table S1 in the supplement at www.int-res.com/articles/ suppl/m458p039_supp.pdf). Two of these species, the spider crab Eurynome aspera and cryptic Galathea spp., died during severe hypoxia (E. aspera: $0.2 \mathrm{ml}$ $\mathrm{DO} \mathrm{l}^{-1}$, Galathea spp.: 0.3 and $0.03 \mathrm{ml} \mathrm{DO} \mathrm{l}^{-1}$ ), whereas the decorator crab Ethusa mascarone, the spider crab Macropodia spp. and the pistol shrimp Alpheus glaber survived the first $8 \mathrm{~h}$ of anoxia. The decapods were followed by the sea urchins Psammechinus

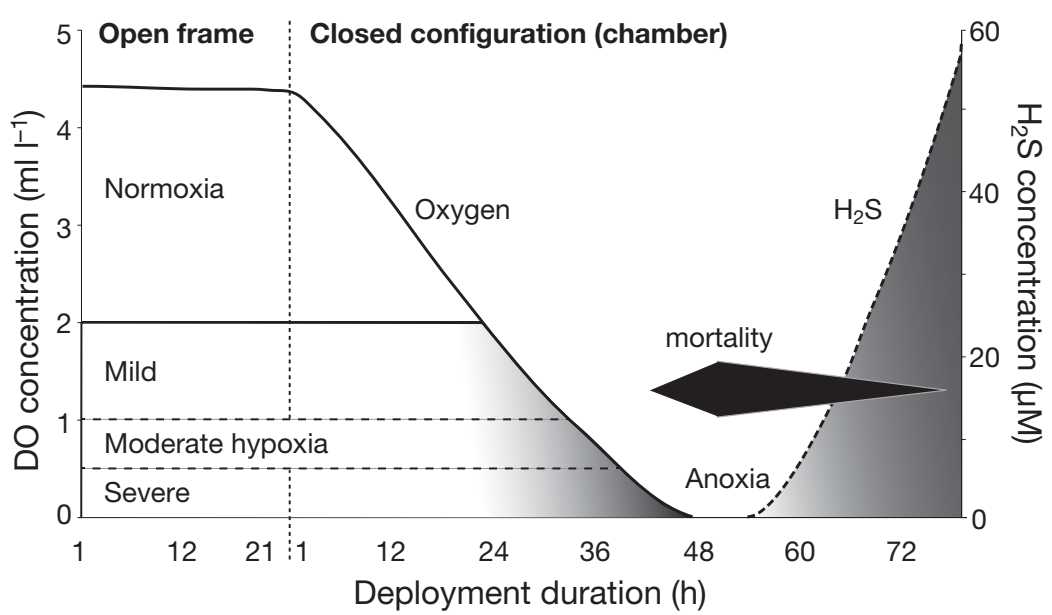

Fig. 1. Representative sensor graph of all deployments (based on averaged values in Table 1). The hypoxia threshold was $2 \mathrm{ml} \mathrm{l}^{-1}$ dissolved oxygen (DO); dashed lines ( 1 and $0.5 \mathrm{ml} \mathrm{l}^{-1} \mathrm{DO}$ ) separate different stages of hypoxia. Black kiteshape schematically indicates onset and course of mortality microtuberculatus and Schizaster canaliferus, of which the latter was the first infaunal species to emerge from the sediment and die (median DO $0.09 \mathrm{ml} \mathrm{l}^{-1}$ ). This was followed by another echinoderm and a designating species of the community, the brittle star Ophiothrix quinquemaculata; mortalities concentrated at the transition from hypoxia to anoxia (hypoxia median DO $0.03 \mathrm{ml} \mathrm{l}^{-1}$, anoxia median duration $6.1 \mathrm{~h}$ ). More tolerant crustaceans included the cryptic Pilumnus spinifer, 4 of 17 individuals died at hypoxia (median DO $0.02 \mathrm{ml} \mathrm{l}^{-1}$ ) and 12 died during anoxia (median duration $7.3 \mathrm{~h}$ ).

Thirteen species (39 individuals) died exclusively during anoxia (Fig. 2B). Among the most sensitive in this group were the infauna brittle stars Amphiura chiajei and Ophiura spp., with mortalities ranging from 8.2 to $19.1 \mathrm{~h}$ of anoxia. More tolerant species included the infauna bivalves Venerupis cf. rhomboides and Abra alba, with mortalities around $28 \mathrm{~h}$, along with the holothurian Ocnus planci (anoxia median duration $23.3 \mathrm{~h}$ ) and the first ascidian species to die, Phallusia mammilata (median $31.7 \mathrm{~h}$ ). The most tolerant decapods included the hermit crab Paguristes eremita, with a median lethal anoxia duration of $42.8 \mathrm{~h}$, followed by the gastropod Hexaplex trunculus (mortalities at h 46.3 and 51.5) and the sea anemone Calliactis parasitica (median $52.5 \mathrm{~h}$ ). Finally, at $76.8 \mathrm{~h}$ of anoxia, 2 of the 10 investigated individuals of the ascidian Microcosmus sulcatus died. 

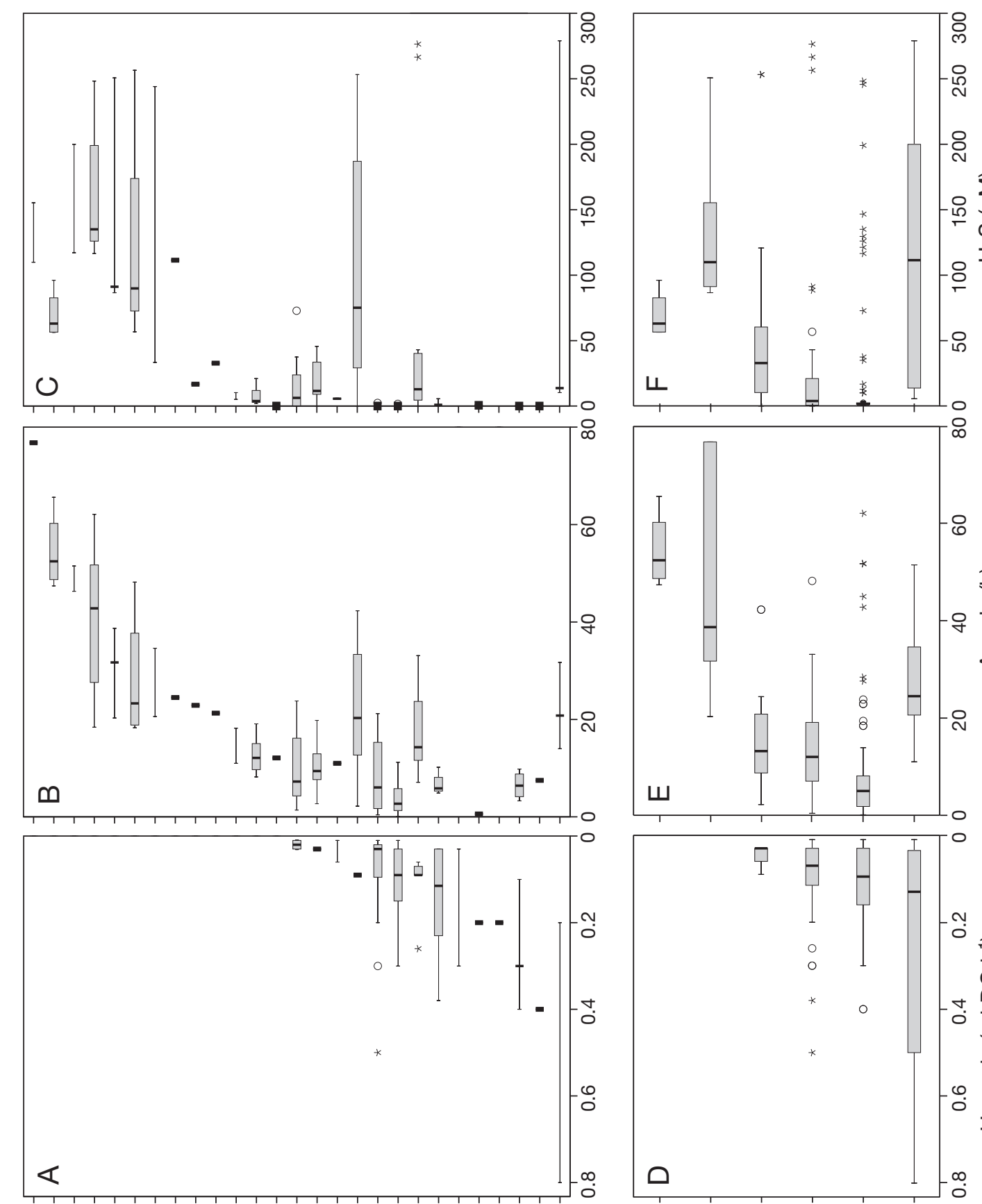

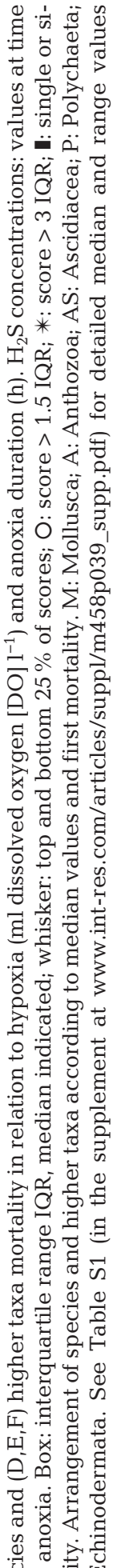

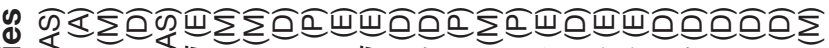

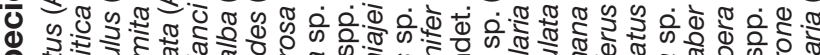

की

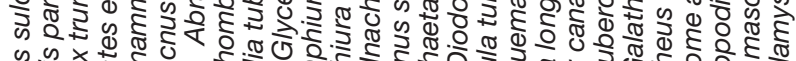

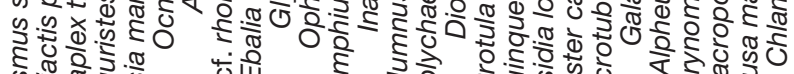
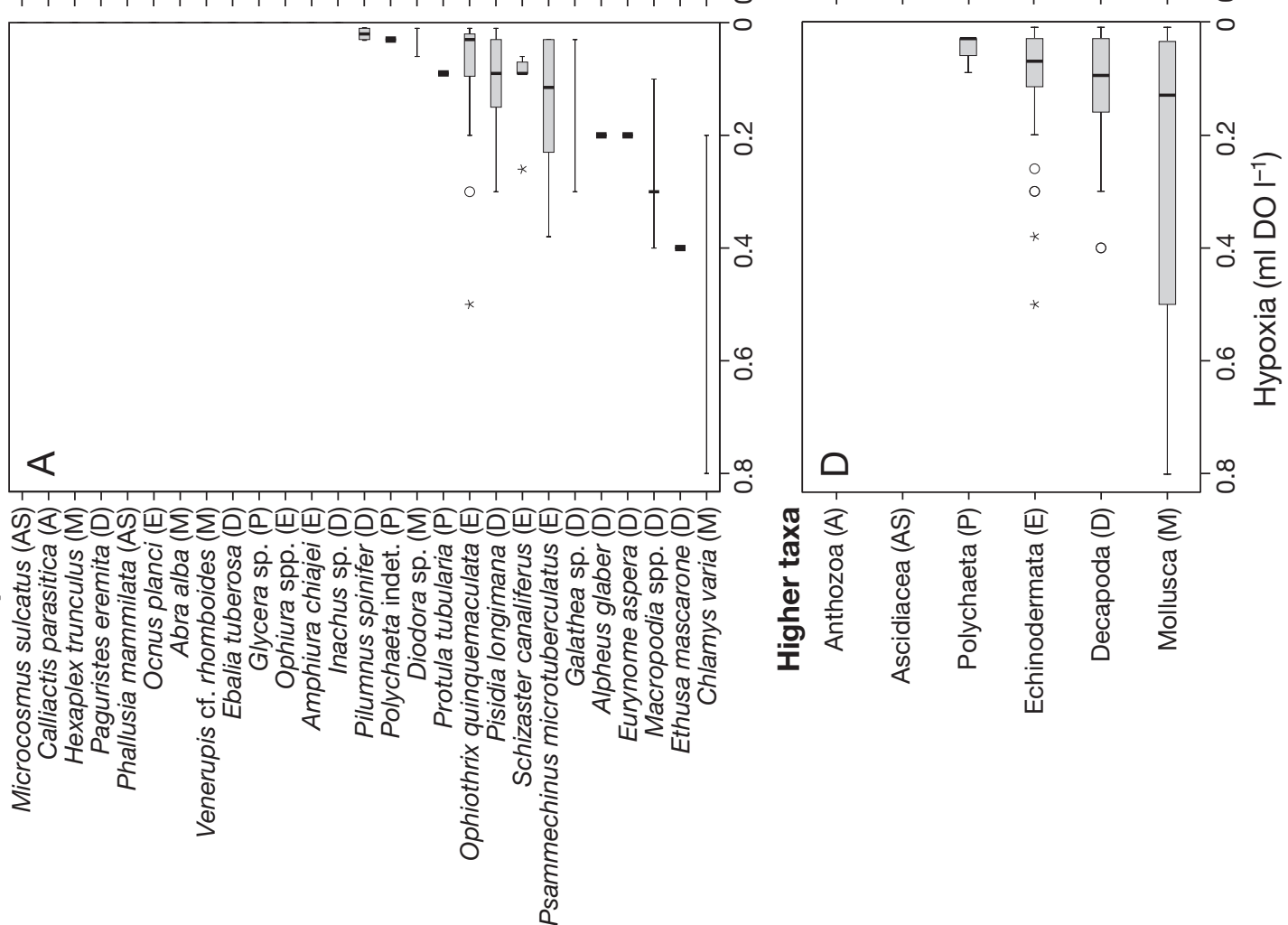

绎要

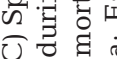

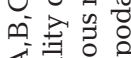

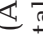

ㄱ. 
Fig. $2 \mathrm{C}$ depicts the respective $\mathrm{H}_{2} \mathrm{~S}$ concentration (min.: $0 \mu \mathrm{M}$, max.: $279 \mu \mathrm{M}$ ) at the time of mortality during anoxia. Importantly, most species died before $\mathrm{H}_{2} \mathrm{~S}$ developed: 200 individuals (24 species) died during hypoxia or anoxia without sulphide, and 99 individuals (23 species) died during anoxia with sulphide present. In general, species with the highest tolerance to anoxia also tolerated high $\mathrm{H}_{2} \mathrm{~S}$ values (Fig. 2C, top). Mortalities at values $>163.6 \mu \mathrm{M}$ all reflect an intermittent $\mathrm{H}_{2} \mathrm{~S}$ peak in one deployment, explaining the high range of $\mathrm{H}_{2} \mathrm{~S}$ values in Chlamys varia (10.3 to $279 \mu \mathrm{M}$ ) and the serpulid tube worm Protula tubularia (0 to $253 \mu \mathrm{M}$ ).

Higher taxa also showed a differentiated sequence and range of mortalities (Fig. 2D-F). The mortalities clearly centred in a narrow window between severe hypoxia (median lethal DO of all taxa $0.09 \mathrm{ml} \mathrm{l}^{-1}$ ) and early anoxia (overall median $7.6 \mathrm{~h}$ ). Decapods were the most sensitive, with mortalities concentrated from $0.09 \mathrm{ml} \mathrm{l}^{-1}$ (median DO) to $4.5 \mathrm{~h}$ (median anoxia duration), followed by echinoderms $\left(0.07 \mathrm{ml} \mathrm{l}^{-1}\right.$ for $12 \mathrm{~h})$ and polychaetes $\left(0.03 \mathrm{ml} \mathrm{l}^{-1}\right.$ for $13.2 \mathrm{~h}$; Fig. 2D). More tolerant higher taxa, i.e. those dying during anoxia only, included ascidians (median $38.7 \mathrm{~h}$ ) and anthozoans (median $52.5 \mathrm{~h}$; Fig. $2 \mathrm{E}$, top). The $\mathrm{H}_{2} \mathrm{~S}$ concentrations at the time of mortality (overall median $0.6 \mu \mathrm{M}$; Fig. 2F) reflect the tolerance to the duration of anoxia in Fig. 2E, i.e. the most tolerant species are again ascidians and anthozoans (median $\mathrm{H}_{2} \mathrm{~S}$ 63.0 to $109.9 \mu \mathrm{M}$ ). The wide plot for molluscs (but mostly from $0.1 \mathrm{ml} \mathrm{l}^{-1}$ median DO to $24.5 \mathrm{~h}$ median anoxia duration) reflects a wide range of tolerances for the different species, intraspecific variances and a few mortalities during the intermittent $\mathrm{H}_{2} \mathrm{~S}$ peak in one deployment.

\section{Critical DO and anoxia ranges}

Mortalities centred at the transition from severe hypoxia to early anoxia, rapidly increasing from 9 individuals at $<0.3 \mathrm{ml}$ to 30 at $<0.2 \mathrm{ml}$ and 90 at $<0.1 \mathrm{ml} \mathrm{DO} \mathrm{l}^{-1}$ (Fig. 3A). The peak mortality was reached within $10 \mathrm{~h}$ of anoxia (94 individuals), dropping by an additional 33 individuals within the next $10 \mathrm{~h}$ and 17 at $30 \mathrm{~h}$. Note that the average $\mathrm{H}_{2} \mathrm{~S}$ concentration across all 11 deployments within the first $10 \mathrm{~h}$ of anoxia was low, i.e. $9.3 \mu \mathrm{M}$. Accordingly, 229 of the 299 mortalities (77\%) occurred before significant $\mathrm{H}_{2} \mathrm{~S}$ development.

The results depict clear declines at the individual, species and higher taxon level (Fig. 3B,C). The overall number of species dropped from initially 40
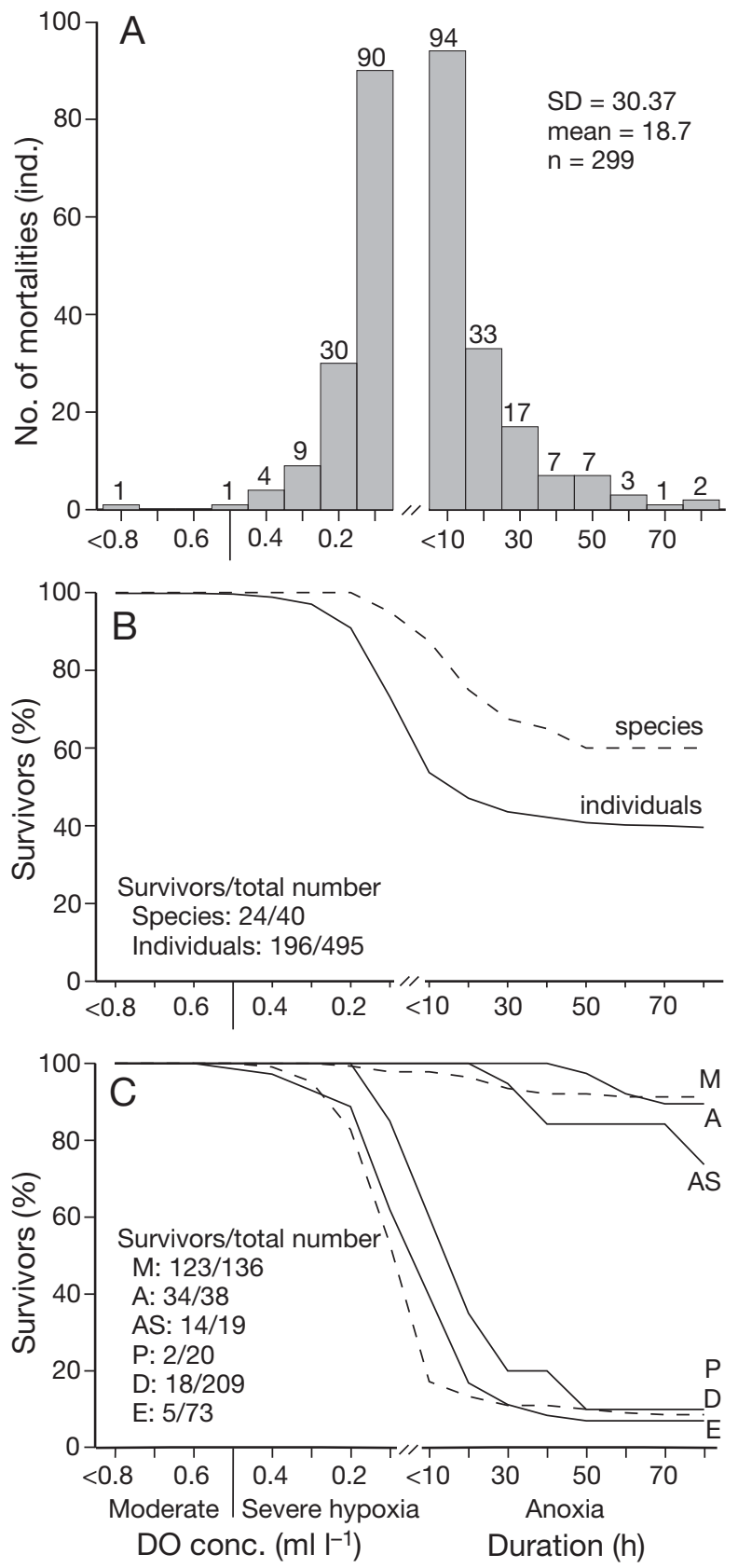

Fig. 3. (A) Number of individuals dying at hypoxia and anoxia $(n=299)$. Survivorship curves of $(B)$ species and individuals and $(\mathrm{C})$ of higher taxa across hypoxia (ml dissolved oxygen [DO] $\mathrm{l}^{-1}$ ) and duration of anoxia (h). Vertical line on $x$-axis separates moderate and severe hypoxia. M: Mollusca; A: Anthozoa; AS: Ascidiacea; P: Polychaeta; D: Decapoda; E: Echinodermata

at normoxia to 38 under hypoxia and to 24 by the end of the experiment, amounting to a total decrease in species abundance of $40 \%$ (see Table 2 in the supplement). The corresponding decrease on the individual level was from 495 to 362 at hypoxia 
to 196 at anoxia (overall decrease $61 \%$ ). Survivorship curves (Fig. 3C) of higher taxa show a clear separation into 2 groups, the first, with lower survival, comprising polychaetes (2 survivors out of 20 individuals), decapods (18 of 209) and echinoderms ( 5 of 73). Their mortality started much earlier (during severe hypoxia) than in the second group, and the steepest decline was at the transition from hypoxia to anoxia. In contrast, the second groupmolluscs, anemones and ascidians - were only minimally reduced even after $80 \mathrm{~h}$ of anoxia (overall decrease 10, 11 and $26 \%$ ), and the decreases occurred primarily under anoxia $( \pm 40 \mathrm{~h})$. The 1 -way repeated measures ANOVA confirmed significant effects of different oxygen conditions (normoxia, hypoxia and anoxia) on the mean abundance of individuals $\left(F_{2,20}=17.9, \mathrm{p}<0.001\right)$, species $\left(F_{1.24,12.42}=\right.$ $19.79, \mathrm{p}<0.001)$ and higher taxa $\left(F_{1.17,11.67}=10.89\right.$, $\mathrm{p}=0.005$ ). Pairwise comparisons of oxygen categories revealed significant differences for all taxonomic levels $(p<0.05)$; the one exception was for higher taxa in the case of normoxia vs. hypoxia $(\mathrm{p}=0.5)$.

Fig. 4A,B shows the percentage of survivors and mortalities within species and higher taxa (for details on the ratio of dead and surviving individuals per species, see also Appendix 1). In only 13 species, 11 of which are molluscs, did all individuals survive. Importantly, based on individuals, $77 \%$ of the survivors were represented by only 2 species (the infaunal bivalve Corbula gibba and the sea anemone Cereus pedunculatus). Survival was high among molluscs $(90 \%)$, anthozoans $(90 \%)$ and ascidians $(74 \%)$ and low in polychaetes, echinoderms and decapods $(10,9$ and $7 \%$, respectively) (Fig. 4B). The echinoderm survivors were 5 infaunal sea urchins Schizaster canaliferus. In the decapods, the survivors were 2 cryptic Nepinnotheres pinnotheres individuals, 13 of 22 hermit crabs Paguristes eremita, 1 of 17 Pilumnus hirtellus and 2 of 3 Ebalia tuberosa. Finally, in the polychaetes, 2 undetermined species survived.

\section{Life habits}

Survivorship curves related to species' substrate relationship, mobility and feeding type showed clear differences in sensitivity patterns (Fig. 5). Epifauna (Fig. 5A) were affected earlier (severe hypoxia) and more strongly than infauna (epifauna reduced from initially 26 to 15 species; overall decrease $42 \%$ ). Cryptic epifauna (see Fig. S1 in the supplement at www.int-res.com/articles/suppl/m453p039_supp. pdf) were especially vulnerable to decreasing oxygen concentrations (overall decrease $60 \%$ ). In infauna, the overall decrease was $36 \%$, with a major drop during anoxia. Repeated measures ANOVAs indicated significant impact of the 3 key oxygen categories on both the epifauna $\left(F_{1.31,13.14}=18.33\right.$, $\mathrm{p}<0.001)$ and infauna $\left(F_{1.32,13.19}=9.13, \mathrm{p}=0.006\right)$. While species abundance in both epi- and infauna dropped significantly from normoxia to anoxia (pairwise comparison, $\mathrm{p}<0.05$ ), the decrease from hypoxia to anoxia was significant only for epifauna (for all epifauna $p=0.007$; cryptic epifauna: $p=0.001$; non-cryptic epifauna $\mathrm{p}=0.027$ ).

Sessile life-forms (Fig. 5B) were more tolerant than mobile forms, with an overall decrease of only $20 \%$ during late anoxia ( $>40 \mathrm{~h}$ of anoxia). The decrease in the number of mobile species was twice as high $(43 \%)$ and already started at severe hypoxia; this corresponds to a drop in the mean number of mobile species per deployment from 11 at normoxia to 9 under hypoxia to 5 during anoxia. The impact of different oxygen categories was significant (repeated measures analyses $F_{2,20}=21.52$, $\mathrm{p}<0.001$ ), and the paired comparisons showed significant differences between normoxia and anoxia $(p=0.001)$ and between hypoxia and anoxia $(\mathrm{p}=0.005)$.

Predators were the first to react under severe hypoxia (overall decrease $53 \%$ ), followed by depositand suspension-feeding species (both decreasing during anoxia by 64 and $67 \%$, respectively) (Fig. 5C). In all feeding types, decreasing oxygen concentrations significantly affected the mean species abundance of suspension feeders $\left(F_{1.08,10.82}=10.56, \mathrm{p}=\right.$ $0.007)$, deposit feeders $\left(F_{2,20}=10.54, \mathrm{p}=0.001\right)$ and predators $\left(F_{2,20}=19.12, \mathrm{p}<0.001\right)$. The pairwise comparisons showed significant differences in all feeding types between normoxia and anoxia $(p<0.05)$ as well as between hypoxia and anoxia (with the exception of deposit feeders, $\mathrm{p}=0.072$ ).

\section{DISCUSSION}

Quantifying ecosystem disturbance or dysfunction is often difficult, even when the damage is visible (e.g. benthic fisheries; Collie et al. 2000). Our in situ approach provides a solid foundation for assessing the response to anoxia as a major source of disturbance by examining mortality as the most clear-cut symptom. Determining the sequence of mortalities and differentiating between the more sensitive and 
Tellina serrata $(\mathrm{M}) 1$

Tellina ovata (M) 1

Dentalium sp. (M) 1

Nassarins cf. pygmaeus (M) 1

Capulus hungaricus (M) 1

Murex brandaris (M) 2

Parvicardium papillosum (M) 3

Fusinus rostratus (M) 4

Nucula nucleus (M) 8

Aporrhais pes-pelecani (M) 8

Corbula gibba (M) 66

Cereus pedunculatus (A) 28 Nepinnotheres pinnotheres (D) 2

Hexaplex trunculus (M) 24

Microcosmus sulcatus (AS) 10

Phallusia mammilata (AS) 9

Ebalia tuberosa (D) 3

Calliactis parasitica (A) 10

Paguristes eremita (D) 25

Diodora sp. (M) 5

Chlamys varia (M) 8

Schizaster canaliferus (E) 22

Polychaeta indet. (P) 17

Pilumnus spinifer (D) 17

Protula tubularia $(\mathrm{P}) 8$

Alpheus glaber (D) 2

Ethusa mascarone (D) 2

Ophiothrix quinquemaculata (E) 26

Macropodia spp. (D) 7

Pisidia longimana (D) 150

Psammechinus microtuberculatus (E) 12

Eurynome aspera (D) 1

Galathea sp. (D) 2

Ocnus planci (E) 4

Ophiura spp. (E) 2

Amphiura chiajei (E) 7

Glycera sp. (P) 1

Inachus sp. (D) 1

Abra alba (M)

Venerupis cf. rhomboides (M) 1

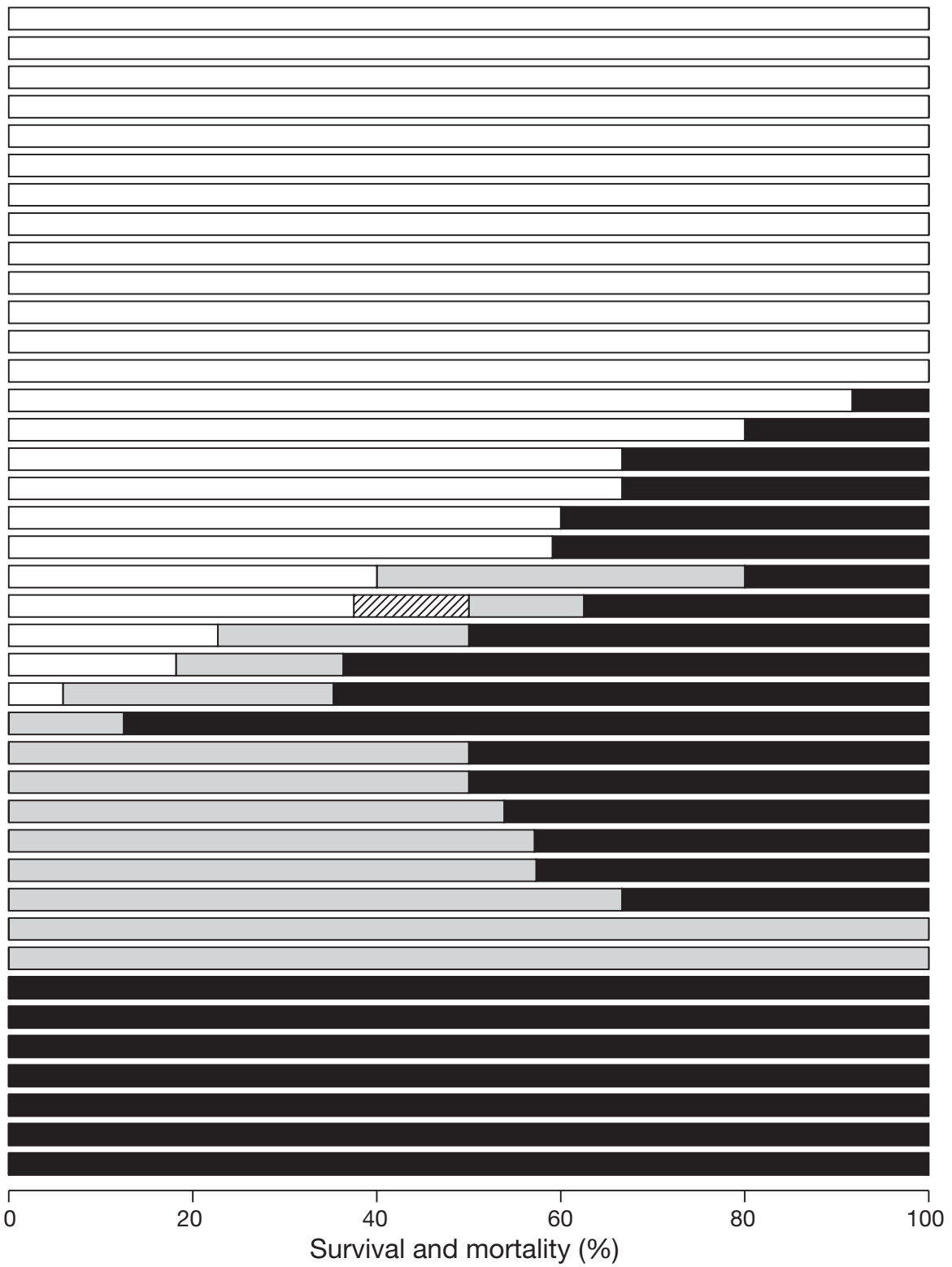

B

\section{Higher taxa}

Mollusca (M) 136

Anthozoa (A) 38

Ascidiacea (AS) 19

Polychaeta $(P) 20$

Decapoda (D) 209

Echinodermata (E) 73

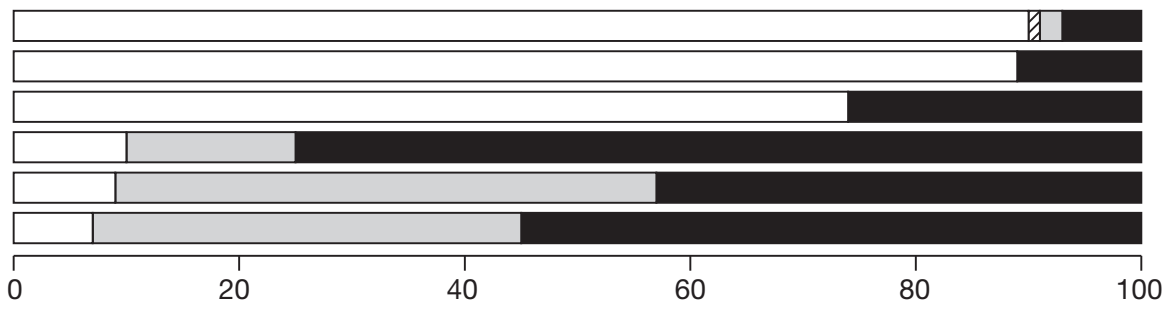

Survival and mortality (\%)

Fig. 4. Survival and mortality of (A) species and (B) higher taxa. Arrangement according to survivors (\%) and mortality in hypoxia or anoxia categories. M: Mollusca; A: Anthozoa; AS: Ascidiacea; P: Polychaeta; D: Decapoda; E: Echinodermata. Number after abbreviation: number of individuals. Total number of individuals analysed: 495 (299 mortalities, 196 survivors; for $\mathrm{n}$, see also Appendix 1) 
more tolerant species ('losers' and 'winners'; Roberts \& Brink 2010) provides a finer resolution and is also a step forward in interpreting post-disturbance community compositions.
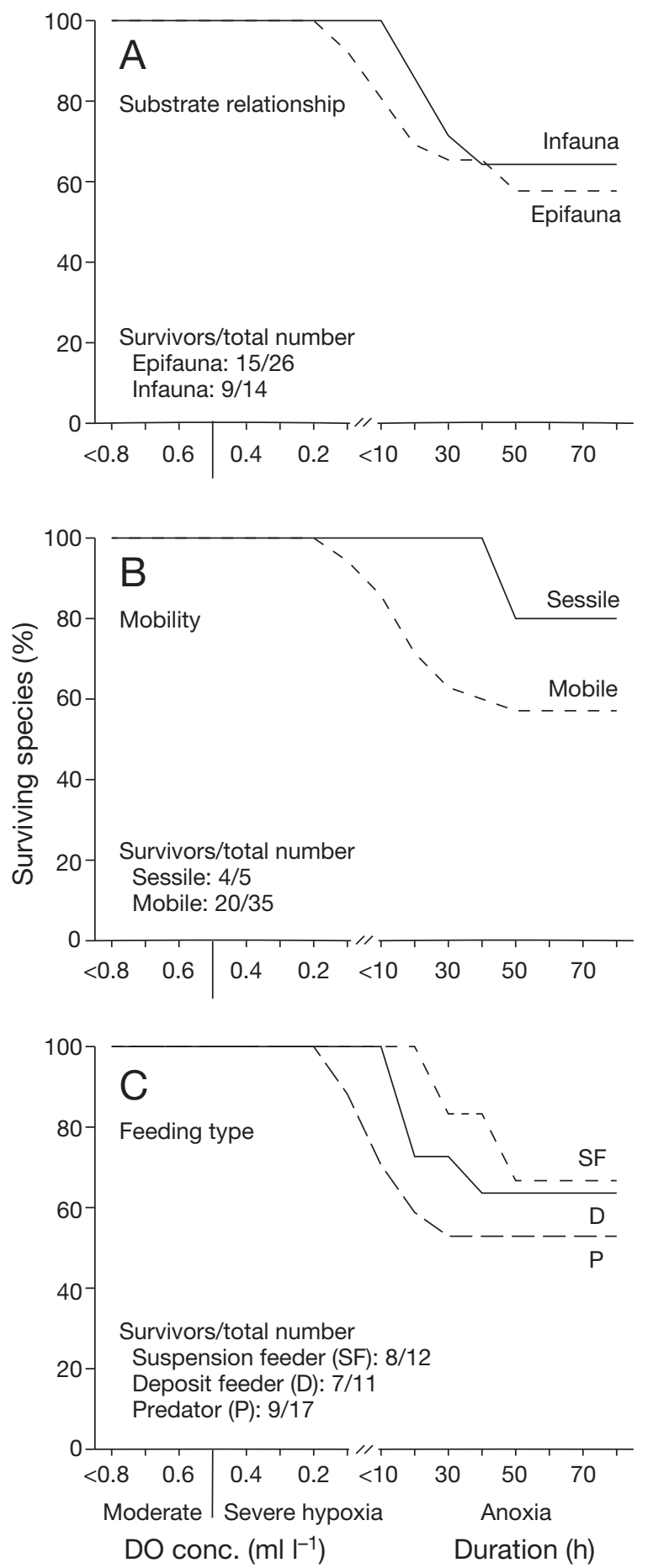

Fig. 5. Survivorship curves of species' life habits across hypoxia (ml dissolved oxygen [DO] $\mathrm{l}^{-1}$ ) and duration of anoxia (h). Vertical line on $x$-axis separates moderate and severe hypoxia

\section{Mortality and survival}

The experiments successfully mimicked the conditions and mortalities observed during earlier mortality events (Stachowitsch 1984). There was a clear sequence in mortality, with decapods, echinoderms and polychaetes showing lower tolerance and ascidians and anthozoans showing distinctly higher tolerance (Fig. 2D,E). While this broadly confirms previous studies (e.g. Diaz \& Rosenberg 1995), the results also present a more nuanced picture by highlighting inter- and intraspecific variability. Molluscs, for example, are generally considered to be more tolerant (in part reflecting metabolic adaptations, e.g. Larade \& Storey 2002). In our study, 13 of the total of 24 species with surviving representatives were molluscs (6 bivalves and 7 gastropods; Fig. 4). At the same time, some molluscs were among the least tolerant, with individuals of mainly 2 species (Chlamys varia and Diodora sp.) exhibiting early mortalities. This level of detail of mortality extends earlier field observations (e.g. Stachowitsch 1984, Jorgensen 1980) as well as recent reviews (e.g. Levin et al. 2009) and meta-analyses (e.g. Vaquer-Sunyer \& Duarte 2008). The earlier field observations of Stachowitsch (1984) were not accompanied by any oxygen measurements. Moreover, the rapidity of the 1983 event and the limits of the diving approach (1 data collection effort per day at $25 \mathrm{~m}$ depth) led to a very coarse resolution of events and a restriction to the most conspicuous species. This new level of resolution on mortalities in the field includes numerous species whose tolerance is very poorly described, such as Phallusia mammilata (Fiala-Medioni 1979) and pea crabs (Stauber 1945). It also contributes significantly to the knowledge of representative soft-bottom groups, including echinoderms (e.g. Psammechinus) and molluscs such as Vetigastropoda (Diodora), Littorinimorpha (Capulus and Aporrhais), Neogastropoda (Fusinus, Hexaplex and Murex), Protobranchia (Nucula), Heterodonta (Parvicardium, Tellina and Timoclea) and scaphopods (Dentalium). Finally, the present study reports species that have rarely been observed in situ (e.g. Alpheus glaber; P. Dworschak pers. comm.).

Our data suggest that most of the macrobenthic invertebrates survive short-term oxygen limitation (1 to $2 \mathrm{~d}$, approximately corresponding to the first half of our closed-chamber experiments) and can therefore tolerate intermittent periods of mild to moderate hypoxia (>0.5 $\mathrm{ml} \mathrm{DO}^{-1}$ ). Severe hypoxia or anoxia, however, marks the critical threshold that compromises ecological integrity. Accordingly, mor- 
tality started relatively late $\left(<0.5 \mathrm{ml} \mathrm{DO} \mathrm{l}^{-1}\right)$ and initially involved a significant drop in individual abundance. The main mortality peak was recorded at a narrow hypoxia-anoxia range (Fig. 3). Subsequent anoxia then considerably impacted the number of species, which dropped by nearly half (40 to 24). Importantly, most mortalities took place before significant $\mathrm{H}_{2} \mathrm{~S}$ development. This in most cases allowed a clear distinction of the roles of these 2 factors, showing that oxygen conditions alone are sufficient to cause quick and widespread community collapse. The drop in $\mathrm{pH}$ from an initial 8.2 to average 7.8 by the end of the deployments represents a considerable change and resembles the predicted $\mathrm{pH}$ scenario for the end of this century. Such a drop could significantly influence organisms' fitness and survival (e.g. Pörtner 2008), although we found no evidence in the literature for the inhibition of organismic activities over short exposure times, such as those in our deployments. Nonetheless, those individuals dying at late anoxia experienced high $\mathrm{H}_{2} \mathrm{~S}$ concentrations and low $\mathrm{pH}$, a combination of stressors that could affect survivorship more than any single factor alone.

Although our deployments do not specifically address the length of exposure to hypoxia, this will no doubt play a role in systems with prolonged hypoxia. In the case of Pisidia longimana and Pilumnus spinifer, for example, mortalities occurred at somewhat higher oxygen concentrations (i.e. earlier) when oxygen decline was slower than when the declines were rapid (e.g. P. longimana, slow decline: lethal DO $0.17 \pm 0.15 \mathrm{ml} \mathrm{l}^{-1}$, steep decline: $0.06 \pm$ $0.07 \mathrm{ml} \mathrm{l}^{-1}$; Haselmair et al. 2010). Nonetheless, both values were close together at the lower end of severe hypoxia and probably would not be altered significantly by a considerably shorter or longer hypoxic period. Importantly, we would also expect the interspecific succession of mortalities to remain the same regardless of hypoxia duration. Finally, the rapidity of the oxygen declines that we induced corresponds well with the course of past anoxia events in the Northern Adriatic: in the 1983 mass mortality event, overall macrofauna biomass dropped quickly by $20 \%$ (Day 1) to $57 \%$ (Day 2) and finally 80 and $92 \%$ (Days 3 and 4, respectively) (Stachowitsch 1986). Our rapid oxygen declines therefore accurately mimicked the speed of events in 'natural' anoxia events here. The time-lapse images support the notion that the habitat complexity created by 3-dimensional biotic community structure can both accelerate mortalities (e.g. sponge associates) and provide important refuges (elevated structures for mobile species to climb up). Note, however, that almost all species showed stress behaviour much earlier, i.e. at mild hypoxia (Riedel et al. 2008a, Haselmair et al. 2010, Pretterebner et al. 2012). Clearly, the community setting and sub-lethal responses must be considered when analysing overall hypoxia-induced impacts.

\section{Life habits}

Incorporating life habits promotes a process-oriented interpretation of ecosystem status. In the $3 \mathrm{key}$ life habit categories (substrate relationship, mobility and feeding type), significant drops occurred in both individuals and species. For a particular ecosystem function, we interpret the individual loss within a taxon as a quantitative decrease in function, whereas the loss of the taxon as a whole is a qualitative decrease in function. The suspension-feeding capacity is a case in point. A particular species typically filters a certain range of particle sizes (e.g. Ward \& Shumway 2004). When some individuals of that species die, then other individuals continue to feed on that particle size, representing a quantitative loss of function. When the species itself is lost, then that particle size range may no longer be filtered out. From the view of the overall filter-feeding capacity, this represents a qualitative change (e.g. altered spectrum of particle sizes filtered out by remaining species); a distinct functional compartment is lost.

The fact that suspension feeders showed the least decline of all feeding types, however, does not imply unimpaired ecosystem function. For example, the service provided by benthic filter-feeding communities as a natural eutrophication control (Officer et al. 1982) may be compromised. Thus, the loss of the brittle star Ophiothrix quinquemaculata (up to 250 individuals per $\mathrm{m}^{2}$; Fedra et al. 1976) but survival of the ascidian Microcosmus sulcatus may represent a major shift in the particle types and sizes removed from the water because these 2 species filter distinct sizes (Gili \& Coma 1998). Sponges, a characteristic group in this benthic community, filter the smallest particles. Their early loss (Stachowitsch 1984) represents another 'qualitative' change in filter-feeding capacity. Clearly, such quantitative and qualitative losses begin even before the last individuals of the particular compartment die ('functional extinction').

Our benthic chamber effectively reduced oxygen but also cut off the food supply to suspension feeders. Although we did not consider this aspect, the relative tolerance of this group makes it unlikely that reduced food supply significantly affected the timing or sequence of mortalities over the short experimental 
periods. This is supported by the finding (Ott \& Fedra 1977) that the benthic community here functions as a stabilizing compartment: energy reserves are accumulated by the large-sized, long-lived macrofauna during times of abundant food and used in times of reduced supply. Such a longer-term stabilizing role of the benthos indicates a minimal impact of a few days without food input from the water column.

Regarding substrate relationship and mobility, infauna was more tolerant than epifauna, and sessile organisms were more tolerant than mobile organisms (Fig. 5). This confirms trends elsewhere. Vistisen \& Vismann (1997), for example, recorded a significantly higher tolerance to both hypoxia and sulphide of the infauna brittle star Amphiura filiformis compared to the epibenthic brittle star Ophiura albida, while Sagasti et al. (2001) reported trends of decreasing tolerance of mobile species relative to sessile species.

Infauna is typically better adapted to oxygen limitation in the upper sediment layer than epifauna, and the fauna from environments that are low in oxygen tend to be more tolerant of low oxygen conditions (for general physiological adaption strategies, see Burnett 1997 and Hagerman 1998). Finally, we argue that many sessile forms might have developed a higher tolerance level for adverse environmental conditions than mobile forms (which can flee). Although our approach did not permit animals to escape from the chamber, it did accommodate almost all species. For example, emerging irregular sea urchins typically moved only a short distance across the sediment before dying, only rarely touching a chamber wall. The more mobile hermit crabs (Pretterebner et al. 2012) and epifaunal brittle stars (Riedel et al. 2008a,b) sought temporary refuge mostly on directly adjoining, elevated multi-species clumps. In anoxic events measuring tens to hundreds or even thousands of square kilometres, the ability to travel somewhat further would not affect the survival of any benthic invertebrate or small benthic fish (e.g. gobies); the extensive and relatively uniform soft-bottom Northern Adriatic shelf provides little refuge beyond the multi-species clumps already enclosed in the chamber. There are no immediately adjoining habitats that would provide more elevated structures to climb onto or that would represent a shallow-water refuge.

\section{Variability}

Despite clear overall patterns of tolerance, we recorded high intraspecific variability. This drawnout loss of individuals supports our conclusion that short-term hypoxia primarily involves quantitative losses rather than fundamentally altered community structure and function. On the taxonomic level, tolerance varies within a species (e.g. life stage; Breitburg 1992, Miller et al. 2002), among species and among higher taxa. Physiological differences, beyond the above-discussed relative mobility, substrate relationship (see also Vaquer-Sunyer \& Duarte 2008) or feeding type, help determine tolerance and survival. Finally, physical and biological community structure can play a role, whereby the loss of 1 species can trigger further species loss, reducing ecosystem stability (O'Gorman et al. 2011). In the study area, for example, the aggregated structure of the epifauna in multi-species clumps may accelerate ecosystem collapse in a positive feedback loop (e.g. emergence and death of cryptic species inhabiting sponges that have died).

The hermit crab Paguristes eremita is an example of a broad intraspecific variability (mortalities after 20 to $60 \mathrm{~h}$ of anoxia). Here, the range may be explained by variations in hermit crab size and weight, the ability to seek temporary refuge (with or without a shell) on top of multi-species clumps and by the degree of $\mathrm{H}_{2} \mathrm{~S}$ exposure (Pretterebner et al. 2012). Such variability provides an evolutionary advantage by buffering the population against stochastic, extreme events (e.g. Denny et al. 2011).

The decapods also provide an example for interspecific variability. In general, they are considered among the most vulnerable organisms (Diaz \& Rosenberg 1995, Vaquer-Sunyer \& Duarte 2008). Here, mortalities began at a DO concentration of $0.4 \mathrm{ml} \mathrm{l}^{-1}$ in the decorator crab Ethusa mascarone. At the other end of the spectrum, individual hermit crabs showed a high tolerance to extended anoxia (median $42.8 \mathrm{~h}$ ) and high $\mathrm{H}_{2} \mathrm{~S}$ (median $135 \mu \mathrm{M}$ ). The most resistant decapods were the pea crab Nepinnotheres pinnotheres (survival: $90 \mathrm{~h}$ of hypoxia and anoxia, maximum $\mathrm{H}_{2} \mathrm{~S}$ concentration $126 \mu \mathrm{M}_{i}$ Haselmair et al. 2010), probably reflecting their life habits in the gill cavity of bivalves or ascidians.

In higher groups, the tolerance range of echinoderms (relatively sensitive), for example, differed dramatically from that of the most tolerant group (anthozoans). In the latter case, the tolerance reflects a combination of behavioural reactions and physiological adaptations (i.e. stretched and raised tentacle crowns or switching to anaerobic metabolism; Shick 1991, Riedel et al. 2008b).

Finally, our results address the current discussion about whether traditional thresholds, if interpreted and applied rigidly, adequately address the above- 
outlined variability (Richards 2011). We argue against a strict interpretation of thresholds gained from experiments designed to reduce the environment to 1 or 2 parameters (oxygen and $\mathrm{H}_{2} \mathrm{~S}$ concentration). Overall, the factors - the presence of additional stressors (Vaquer-Sunyer \& Duarte 2010), different inherent tolerances of organisms, structural habitat conditions (Godbold et al. 2011) that can increase or decrease survival, behavioural responses such as aggregation on elevated structures and interactions between such aggregated organisms, and susceptibility to predators-represent difficult-to-predict and potentially confounding influences on the effects of hypoxia on benthic communities. Nonetheless, they can influence survival in many ways and should be considered, together, in realistic assessments.

Clearly, the survival of tolerant species ('winners' sensu Roberts \& Brink 2010) does not make a 'winning' community. Approaches that incorporate the full range of benthic reactions, from initial behavioural responses to mortalities and surviving species, can go beyond gauging the current status of a community based on the immediate condition of the component species. Coupled with additional information (e.g. on growth rates and immigration), these approaches can even be used to help reconstruct the severity and timing of past disturbances based on the composition and sizes of remaining species. Such knowledge is a prerequisite for informed management decisions regarding species and ecosystem protection.

Acknowledgements. The present study was financed by the Austrian Science Fund (FWF; projects P17655-B03 and P21542-B17). We thank C. Baranyi, J. Hohenegger and A. Stargardt for help with data analysis and graphics and the directors (V. Malacic and A. Malej) and staff at the Marine Biology Station (MBS) Piran, Slovenia, for their great hospitality and support during the fieldwork. Finally, we thank 3 anonymous reviewers for their stimulating suggestions, which we were happy to incorporate.

\section{LITERATURE CITED}

Breitburg D (1992) Episodic hypoxia in Chesapeake Bay: Interacting effects of recruitment, behavior, and physical disturbance. Ecol Monogr 62:525-546

Burnett LE (1997) The challenge of living in hypoxic and hypercapnic aquatic environments. Am Zool 37:633-640

Butchart SHM, Walpole M, Collen B, Van Strien A and others (2010) Global biodiversity: indicators of recent declines. Science 328:1164-1168

Collie JS, Hall SJ, Kaiser MJ, Poiner IR (2000) A quantitative analysis of fishing impacts on shelf-sea benthos. J Anim Ecol 69:785-798

Conley DJ, Carstensen J, Vaquer-Sunyer R, Duarte CM (2009) Ecosystem thresholds with hypoxia. Hydrobiolo- gia 629:21-29

Denny MW, Wesley Dowd W, Bilir L, Mach KJ (2011) Spreading the risk: small-scale body temperature variation among intertidal organisms and its implications for species persistence. J Exp Mar Biol Ecol 400:175-190

Diaz RJ, Rosenberg R (1995) Marine benthic hypoxia: a review of its ecological effects and the behavioural responses of benthic macrofauna. Oceanogr Mar Biol Annu Rev 33:245-303

> Diaz RJ, Rosenberg R (2008) Spreading dead zones and consequences for marine ecosystems. Science 321:926-929

> Farrell AP, Richards JG (2009) Defining hypoxia: an integrative synthesis of the responses of fish to hypoxia. Fish Physiol 27:487-503

Fedra K, Ölscher EM, Scherübel C, Stachowitsch M, Wurzian RS (1976) On the ecology of a North Adriatic benthic community: distribution, standing crop and composition of the macrobenthos. Mar Biol 38:129-145

Fiala-Medioni (1979) Effects of oxygen tension on pumping, filtration and oxygen uptake in the ascidian Phallusia mammilata. Mar Ecol Prog Ser 1:49-53

Gili JM, Coma R (1998) Benthic suspension feeders: their paramount role in littoral marine food webs. Trends Ecol Evol 13:316-321

Godbold JA, Bulling MT, Solan M (2011) Habitat structure mediates biodiversity effects on ecosystem properties. Proc R Soc Ser B Biol Sci 278:2510-2518

> Gray JS, Wu RS, Or YY (2002) Effects of hypoxia and organic enrichment on the coastal marine environment. Mar Ecol Prog Ser 238:249-279

Gruber N (2011) Warming up, turning sour, losing breath: ocean biogeochemistry under global change. Philos Trans R Soc Lond A 369:1980-1996

Hagerman L (1998) Physiological flexibility; a necessity for life in anoxic and sulphidic habitats. Hydrobiologia 375/ 376:241-254

Halpern BS, Walbridge S, Selkoe KA, Kappel CV and others (2008) A global map of human impact on marine ecosystems. Science 319:948-952

Haselmair A, Stachowitsch M, Zuschin M, Riedel B (2010) Behaviour and mortality of benthic crustaceans in response to experimentally induced hypoxia and anoxia in situ. Mar Ecol Prog Ser 414:195-208

Hrs-Brenko M, Medakovic D, Labura Z, Zahtila E (1994) Bivalve recovery after a mass mortality in the autumn of 1989 in the northern Adriatic Sea. Period Biol 96:455-458

Jackson JBC (2008) Ecological extinction and evolution in the brave new ocean. Proc Natl Acad Sci USA 105: 11458-11465

> Jackson JBC, Kirby MX, Berger WH, Bjorndal KA and others (2001) Historical overfishing and the recent collapse of coastal ecosystems. Science 293:629-637

> Jorgensen BB (1980) Seasonal oxygen depletion in the bottom waters of a Danish fjord and its effect on the benthic community. Oikos 34:68-76

Justic D (1987) Long-term eutrophication of the northern Adriatic Sea. Mar Pollut Bull 18:281-284

Keeling RF, Körtzinger A, Gruber N (2010) Ocean deoxygenation in a warming world. Annu Rev Mar Sci 2: 199-229

Larade K, Storey KB (2002) A profile of the metabolic responses to anoxia in marine invertebrates. In: Storey KB, Storey JM (eds) Cell and molecular responses to stress. Elsevier Press, Amsterdam, p 27-46

Levin LA, Ekau W, Gooday AJ, Jorissen F and others (2009) 
Effects of natural and human-induced hypoxia on coastal benthos. Biogeosciences 6:2063-2098

Link JS (2005) Translating ecosystem indicators into decision criteria. ICES J Mar Sci 62:569-576

> Long WC, Brylawski BJ, Seitz RD (2008) Behavioral effects of low dissolved oxygen on the bivalve Macoma balthica. J Exp Mar Biol Ecol 359:34-39

Lotze HK, Lenihan HS, Bourque BJ, Bradbury RH and others (2006) Depletion, degradation, and recovery potential of estuaries and coastal seas. Science 312:1806-1809

Middelburg JJ, Levine LA (2009) Coastal hypoxia and sediment biogeochemistry. Biogeosciences 6:1273-1293

- Miller DC, Poucher SL, Coiro L (2002) Determination of lethal dissolved oxygen levels for selected marine and estuarine fishes, crustaceans, and a bivalve. Mar Biol 140:287-296

O'Gorman EJ, Yearsley JM, Crowe TP, Emmerson MC, Jacob U, Petchey OL (2011) Loss of functionally unique species may gradually undermine ecosystems. Proc R Soc Lond B 278:1886-1893

Officer CB, Smayda TJ, Mann R (1982) Benthic filter feeding: a natural eutrophication control. Mar Ecol Prog Ser 9:203-210

Ott J, Fedra K (1977) Stabilizing properties of a high-biomass benthic community in a fluctuating ecosystem. Helgol Mar Res 30:485-494

> Pörtner HO (2008) Ecosystem effects of ocean acidification in times of ocean warming: a physiologists's view. Mar Ecol Prog Ser 373:203-217

Pretterebner K, Riedel B, Zuschin M, Stachowitsch M (2012) Hermit crabs and their symbionts: reactions to artificially induced anoxia on a sublittoral sediment bottom. J Exp Mar Biol Ecol 10:23-33

Rabalais NN, Diaz RJ, Levin LA, Turner RE, Gilbert D, Zhang J (2010) Dynamics and distribution of natural and human-caused hypoxia. Biogeosciences 7:585-619

Richards JG (2011) Physiological, behavioral and biochemical adaptations of intertidal fishes to hypoxia. J Exp Biol 214:191-199

Riedel B, Zuschin M, Haselmair A, Stachowitsch M (2008a) Oxygen depletion under glass: behavioural responses of benthic macrofauna to induced anoxia in the northern Adriatic. J Exp Mar Biol Ecol 367:17-27

Riedel B, Stachowitsch M, Zuschin M (2008b) Sea anemones and brittle stars: unexpected predatory interactions during induced in situ oxygen crises. Mar Biol 153: 1075-1085

Roberts SJ, Brink K (2010) Managing marine resources sustainably. Environment 52:44-52

Sagasti A, Schaffner LC, Duffy JE (2001) Effects of periodic hypoxia on mortality, feeding and predation in an estuarine epifaunal community. J Exp Mar Biol Ecol 258: $257-283$

Sala E, Knowlton N (2006) Global marine biodiversity trends. Annu Rev Environ Resour 31:93-122

Salas F, Marcos C, Neto JM, Patricio J, Perez-Ruzafa A, Mar- ques JC (2006) User-friendly guide for using benthic ecological indicators in coastal and marine quality assessment. Ocean Coast Manag 49:308-331

Shick JM (1991) A functional biology of sea anemones. Chapman \& Hall, New York, NY

Shimps E, Rice JA, Osborne JA (2005) Hypoxia tolerance in two juvenile estuary-dependent fishes. J Exp Mar Biol Ecol 325:146-162

Solan M, Cardinale BJ, Downing AL, Engelhardt KAM, Ruesink JL, Srivastava DS (2004) Extinction and ecosystem function in the marine benthos. Science 306:1177-1180

- Stachowitsch M (1984) Mass mortality in the Gulf of Trieste: the course of community destruction. PSZNI Mar Ecol 5: 243-264

Stachowitsch M (1986) The Gulf of Trieste: a sensitive ecosystem. Nova Thalassia 8:221-235

Stachowitsch M, Avcin A (1988) Eutrophication-induced modifications of benthic communities. In: Eutrophication of the Mediterranean Sea: receiving capacity and monitoring of long-term effects, Vol 49. Unesco Technical Reports in Marine Science, Bologna, p 67-80

Stachowitsch M, Riedel B, Zuschin M, Machan R (2007) Oxygen depletion and benthic mortalities: the first in situ experimental approach to documenting an elusive phenomenon. Limnol Oceanogr Methods 5:344-352

- Stauber LA (1945) Pinnotheres ostreum, parasitic on the American oyster, Ostrea (Gryphaea) virginica. Biol Bull (Woods Hole) 88:269-291

Vaquer-Sunyer R, Duarte CM (2008) Thresholds of hypoxia for marine biodiversity. Proc Natl Acad Sci USA 105: 15452-15457

> Vaquer-Sunyer R, Duarte CM (2010) Sulfide exposure accelerates hypoxia-driven mortality. Limnol Oceanogr 55: 1075-1082

Vaquer-Sunyer R, Duarte CM (2011) Temperature effects on oxygen thresholds for hypoxia in marine benthic organisms. Glob Change Biol 17:1788-1797

> Vistisen B, Vismann B (1997) Tolerance to low oxygen and sulfide in Amphiura filiformis and Ophiura albida (Echinodermata: Ophiuroidea). Mar Biol 128:241-246

Wang Y, Hu M, Shin PKS, Cheung SG (2010) Induction of anti-predator responses in the green-lipped mussel Perna viridis under hypoxia. Mar Biol 157:747-754

Ward JE, Shumway SE (2004) Separating the grain from the chaff: particle selection in suspension and deposit-feeding bivalves. J Exp Mar Biol Ecol 300:83-130

Worm B, Barbier EB, Beaumont N, Duffy JE and others (2006) Impacts of biodiversity loss on ocean ecosystem services. Science 314:787-790

Zhang J, Gilbert D, Gooday AJ, Levin L and others (2010) Natural and human-induced hypoxia and consequences for coastal areas: synthesis and future development. Biogeosciences 7:1443-1467

Zuschin M, Stachowitsch M (2009) Epifauna-dominated benthic shelf assemblages: lessons from the modern Adriatic Sea. Palaios 24:211-221 
Appendix 1. Macrobenthic species (40 taxa) recorded. Higher taxa: Anthozoa, Mollusca, Polychaeta, Decapoda, Echino-

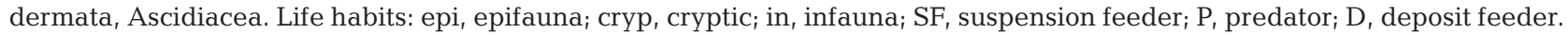
na: not applicable

\begin{tabular}{|c|c|c|c|c|}
\hline $\begin{array}{l}\text { Higher taxa } \\
\text { Species }\end{array}$ & $\begin{array}{l}\text { Abundance } \\
\text { total }\end{array}$ & $\begin{array}{c}\text { Ratio } \\
\text { Living:Dead }\end{array}$ & $\begin{array}{l}\text { Life } \\
\text { habits }\end{array}$ & Final, pre-mortality behaviour \\
\hline \multicolumn{5}{|l|}{ Anthozoa } \\
\hline Calliactis parasitica & 10 & $6: 4$ & epi, sessile, D & tentacle crown movement \\
\hline Cereus pedunculatus & 28 & $28: 0$ & epi, sessile, SF & na \\
\hline \multicolumn{5}{|l|}{ Mollusca } \\
\hline \multicolumn{5}{|l|}{ Gastropoda } \\
\hline Aporrhais pespelecani & 8 & $8: 0$ & in, mobile, D & na \\
\hline Capulus hungaricus & 1 & $1: 0$ & epi, mobile, SF & na \\
\hline Diodora sp. & 5 & $2: 3$ & epi, mobile, $\mathrm{P}$ & body movement (foot), locomotion \\
\hline Fusinus rostratus & 4 & $4: 0$ & epi, mobile, $\mathrm{P}$ & na \\
\hline Hexaplex trunculus & 24 & $22: 2$ & epi, mobile, $\mathrm{P}$ & body movement (foot), locomotion \\
\hline Nassarius cf. pygmaeus & 1 & $1: 0$ & epi, mobile, $\mathrm{P}$ & na \\
\hline Murex brandaris & 2 & $2: 0$ & epi, mobile, $\mathrm{P}$ & na \\
\hline \multicolumn{5}{|l|}{ Scaphopoda } \\
\hline Dentalium sp. & 1 & $1: 0$ & in, mobile, D & na \\
\hline \multicolumn{5}{|l|}{ Bivalvia } \\
\hline Abra alba & 2 & $0: 2$ & in, mobile, D & body movement (siphon) \\
\hline Chlamys varia & 8 & $3: 5$ & epi, mobile, SF & sustained valve gap, mantle retraction \\
\hline Corbula gibba & 66 & 66:0 & in, mobile, $\mathrm{SF}$ & na \\
\hline Nucula nucleus & 8 & $8: 0$ & in, mobile, $\mathrm{D}$ & na \\
\hline Parvicardium papillosum & 3 & $3: 0$ & in, mobile, $\mathrm{SF}$ & na \\
\hline Tellina serrata & 1 & $1: 0$ & in, mobile, D & na \\
\hline Timoclea ovata & 1 & $1: 0$ & in, mobile, $\mathrm{SF}$ & na \\
\hline Venerupis cf. rhomboides & 1 & $0: 1$ & in, mobile, $\mathrm{SF}$ & body movement (foot \& siphon) \\
\hline \multicolumn{5}{|l|}{ Polychaeta } \\
\hline indeterminate species & 11 & $2: 9$ & in, mobile, D/P & body movement \\
\hline Glycera sp. & 1 & $0: 1$ & in, mobile, $\mathrm{P}$ & body movement \\
\hline Protula tubularia & 8 & $0: 8$ & epi, sessile, SF & tentacle crown movement \\
\hline \multicolumn{5}{|l|}{ Decapoda } \\
\hline Alpheus glaber & 2 & $0: 2$ & epi, mobile, D & body movement (legs) \\
\hline Ebalia tuberosa & 3 & $2: 1$ & epi, mobile, $\mathrm{P}$ & body movement (legs) \\
\hline Ethusa mascarone & 2 & $0: 2$ & epi/cryp, mobile, $\mathrm{P}$ & body movement (legs) \\
\hline Eurynome aspera & 1 & $0: 1$ & epi, mobile, $\mathrm{P}$ & body movement (legs) \\
\hline Galathea spp. & 2 & $0: 2$ & epi/cryp, mobile, $\mathrm{P}$ & body movement (legs) \\
\hline Inachus sp. & 1 & $0: 1$ & epi, mobile, $\mathrm{P}$ & body movement (legs) \\
\hline Macropodia spp. & 7 & $0: 7$ & epi, mobile, $\mathrm{P}$ & body movement (legs) \\
\hline Nepinnotheres pinnotheres & 2 & $2: 0$ & epi/cryp, mobile, $\mathrm{P}$ & na \\
\hline Paguristes eremita & 22 & $13: 9$ & epi, mobile, $\mathrm{P}$ & body movement, locomotion \\
\hline Pilumnus spinifer & 17 & $1: 16$ & epi/cryp, mobile, $\mathrm{P}$ & body movement (legs) \\
\hline Pisidia longimana & 150 & $0: 150$ & epi/cryp, mobile, $\mathrm{P}$ & body movement (legs) \\
\hline \multicolumn{5}{|l|}{ Echinodermata } \\
\hline \multicolumn{5}{|l|}{ Holothuroidea } \\
\hline Ocnus planci & 4 & $0: 4$ & epi, mobile, SF & tentacle crown movement \\
\hline \multicolumn{5}{|l|}{ Echinoidea } \\
\hline Psammechinus microtuberculatus & tus 12 & $0: 12$ & epi, mobile, D & locomotion \\
\hline Schizaster canaliferus & 22 & $5: 17$ & in, mobile, $\mathrm{D}$ & locomotion \\
\hline \multicolumn{5}{|l|}{ Ophiuroidea } \\
\hline Ophiothrix quinquemaculata & 26 & $0: 26$ & epi, mobile, SF & body movement (arms) \\
\hline Ophiura spp. & 2 & $0: 2$ & inf, mobile, D & body movement (arms), locomotion \\
\hline Amphiura chiajei & 7 & $0: 7$ & inf, mobile, D & body movement (arms), locomotion \\
\hline \multicolumn{5}{|l|}{ Ascidiacea } \\
\hline Microcosmus sulcatus & 10 & $8: 2$ & epi, sessile, SF & body contraction \\
\hline Phallusia mammilata & 9 & $6: 3$ & epi, sessile, SF & body contraction \\
\hline
\end{tabular}

